\title{
An analysis of research developments and opportunities in tourism, poverty alleviation and nature conservation
}

\author{
V. C. Tassone \& V. R. Van der Duim \\ Socio-Spatial Analysis Group, Wageningen University, The Netherlands
}

\begin{abstract}
Sustainable tourism development is increasingly put forward as a promising mechanism for poverty alleviation and nature conservation. However, to date, knowledge about theories, roles and the practical contribution of tourism arrangements, policy and plans in relation to poverty alleviation and nature conservation still appears to be under a process of experimentation. Research studies are scattered and there is a clear need to systematize the knowledge produced. This paper aims to address this need by analyzing a number of papers, discussing tourism, poverty alleviation and nature conservation issues, that were published in 17 scientific journals related to social science during the period 2003-2006. It classifies past research developments and research knowledge produced and identifies research gaps and opportunities by taking into account societal needs.
\end{abstract}

Keywords: tourism, poverty alleviation, nature conservation, sustainability.

\section{Introduction}

In recent years the dominant discourse on sustainable development has drawn attention to the need to link nature conservation and poverty alleviation issues. As a consequence poverty alleviation- and environmental conservation-oriented policies, plans and strategies turned out to be top priorities in the international agenda (e.g. MEA [55]; NEPAD [60]; UN [86]; World Bank [90]). However, to date, knowledge about theories, roles and the practical contribution of tourism arrangements, policy and plans in relation to poverty alleviation and nature conservation still appears to be under a process of debate and experimentation and there is the need to systematize the knowledge produced in recent years. 
Some recent studies have analyzed the making and the evolution of tourism academic knowledge and have provided some interesting results about trends and productivity in scientific research (Jogaratnam et al. [34]; Xiao and Smith [92]; Xiao and Smith [93]). These studies however examined tourism research from a broad perspective, and they did not specifically look at the knowledge generated in the field of tourism, nature conservation and poverty reduction.

This study aims to address this gap. By analyzing 83 scientific papers published in 17 different social science journals from 2003 to 2006 and discussing tourism, poverty alleviation and nature conservation issues, this study provides an indication of the direction of past scientific research work and explores research gaps and opportunities also taking into account societal need. Ultimately the findings of this analysis may guide and inspire a future research agenda.

This paper first presents the method used for mapping scientific knowledge. Then, it examines the main research topics, the modes of knowledge production and geographical focus of past studies. Additionally, and based on the findings described in the previous sections, it discusses about societal needs and future research opportunities.

\section{Analysis of research developments: the method}

In order to identify the knowledge produced in tourism, poverty reduction and nature conservation, a number of scientific past studies discussing these issues are analyzed. Time constraints and practicalities imposed a restriction with regard to the types and numbers of studies to be examined. A total number of 17 journals that could represent the richness and variety of social sciences perspectives and disciplines were selected, including top journals in the tourism field and journals dealing with sustainability and global change issues. The selected journals are: Annals of Tourism research, Current Issues in Tourism, Journal of Ecotourism, Journal of Sustainable Tourism, Journal of Tourism Research, Journal of Travel Research, Tourism Economics, Tourism Management, Tourist Studies and also Biodiversity and Conservation, Ecological Economics, Environmental and Development Economics, Environment Development and Sustainability, Environmental Monitoring and Assessment, Journal of Environmental Management, International Environmental Management, World Development.

Then, a number of articles published in these journals in the period 20032006 were selected. This selection is made by using a number of keywords that directly or indirectly address some typical issues in tourism, poverty reduction and nature protection. The articles selected are those that contain in the title words and/or paper's keywords at least one of the following keywords: sustainability, community, stakeholder, poverty, nature, environment, protected area, impact, management, decision making, social, cultural, fund raising, market mechanisms and that discusses in a general or specific manner issues related to sustainable tourism, poverty reduction and nature conservation. 
To clarify, this means that a paper is not included in the analysis if for example the article has as keyword one of the keywords listed above but does not refer to the issues we are discussing in this report. Due to time constraints we have not taken into account (and therefore not included as keywords) other important issues and aspects, for example pollution problems, climate change, specific sea-coastal tourism issues, city tourism, etc. that are gaining more and more attention in the research agenda. The total number of articles selected is 83 . Although the analysis does not include all existing papers ever published in the field of tourism, nature conservation and poverty reduction, it is believed that the papers selected provide a suitable representation of research studies carried out in this field in the past years.

\section{Analysis of research developments: the results}

\subsection{Analysis of research topics}

The papers selected according to keywords as explained above are firstly sorted out according to the main theme they refer to. A total of four themes are identified, namely: 1.Tourism and Poverty Reduction; 2.Tourism and Nature Conservation; 3.Tourism, Poverty Reduction and Nature Conservation; 4.Tourism and Sustainability. Secondly, the selected papers are classified within each theme according to the specific topic they address.

Only one main topic addressed in each paper is taken into account. This means that if a study simultaneously addresses more than one topic, this study will be classified only according to the main topic discussed. Topics are identified and classified by analyzing the specific aim and key research questions that each selected paper is addressing. Table 1 presents the selected papers classified by theme and topic.

\subsection{Analysis of modes of knowledge production}

Although, in practice, the choice of a research topic depends on a number of factors (e.g. the interest of the researcher, negotiation with financing institutes), analytically we can make a distinction between two ways in which the selection of a research topic is made (see also Lengkeek and Platenkamp [43]). First, a wide variety of practical concerns may present topics for research. In this mode of knowledge production research is first and foremost problem-oriented. The knowledge produced by research is oriented towards (possible) application and use. This type of knowledge production often accepts the socio-political, economic or cultural context as given and source of problem. Second, an equally wide range of topics for research derives from scientific and intellectual interest. Here the research is concept-oriented, that is oriented towards development of theory, concepts and (new) methodologies, which should enable us to explain societal phenomenon (in a more positivistic tradition) or to interpret and understand meanings in a more phenomenological perspective. Here concepts are, as far as possible, abstracted from the daily context. 
Table 1: $\quad$ Studies classified according to theme and topic.

\begin{tabular}{|c|c|c|}
\hline \multicolumn{2}{|r|}{ Tourism-Poverty } & $\mathrm{Nr}$ \\
\hline $\begin{array}{l}\text { Ex-post impact } \\
\text { evaluation }\end{array}$ & $\begin{array}{l}\text { Clifton and Benson [10]; Dyer et al. [14]; Nyaupane } \\
\text { et al. [63]; Saayman and Saayman [72] }\end{array}$ & 4 \\
\hline $\begin{array}{l}\text { Community } \\
\text { participation }\end{array}$ & Briedenhann and Wickens [6]; Tosun [84] & 2 \\
\hline \multicolumn{3}{|c|}{ Tourism-Nature } \\
\hline $\begin{array}{l}\text { Ethics and } \\
\text { discourses }\end{array}$ & Jamal et al. [33]; Holden [30]; Shultis and Way [74] & 3 \\
\hline $\begin{array}{l}\text { Ex-post impact } \\
\text { evaluation }\end{array}$ & $\begin{array}{l}\text { Hill and Pickering [29]; Kuvan [40]; Li et al. [48]; Li } \\
\text { et al. [49]; Priskin [71] }\end{array}$ & 5 \\
\hline Management & $\begin{array}{l}\text { Brown [5]; Buultjens et al. [4]; Cheng et al. [7]; Gios } \\
\text { et al. [22]; Hannam [24]; Henderson [27]; Kenneth et } \\
\text { al. [36]; Kruger [39]; Li [46]; Mason [52]; Phillips } \\
\text { and Jones [70]; Okello and Kiringe [65]; Sorice et al. } \\
\text { [77]; Stein et al. [80]; Tisdell and Wilson [83]; } \\
\text { Wachowiak [89] }\end{array}$ & 16 \\
\hline $\begin{array}{l}\text { Environmental } \\
\text { performance of } \\
\text { tourism } \\
\text { enterprises }\end{array}$ & $\begin{array}{l}\text { Clarke [9]; Herremans et al. [28]; Masau and } \\
\text { Brideaux [51]; Spenceley [79]; Van der Duim and } \\
\text { van Marwijk [87] }\end{array}$ & 5 \\
\hline $\begin{array}{l}\text { Financing } \\
\text { mechanisms }\end{array}$ & Alpizar [1] & 1 \\
\hline $\begin{array}{l}\text { Stakeholder } \\
\text { roles, values } \\
\text { and } \\
\text { partnerships }\end{array}$ & $\begin{array}{l}\text { Buckley [3]; De Oliveira [13]; Duffy [15]; } \\
\text { Fairweather et al. [16]; Fennell and Butler [19]; } \\
\text { Lewis and Newsome [44]; Medina [56]; Naidoo and } \\
\text { Adamowicz [58]; Nyaupane et al. [64]; Svoronou } \\
\text { and Holden [82]; Wurzinger and Johansson [91] }\end{array}$ & 11 \\
\hline \multicolumn{3}{|c|}{ Tourism-Poverty-Nature } \\
\hline $\begin{array}{l}\text { Ex-post en } \\
\text { ex-ante impact } \\
\text { evaluation }\end{array}$ & $\begin{array}{l}\text { Ex-post: Gossling [23]; Kontogeorgopoulos [38]; } \\
\text { Silori [75]; Stone and Wall [81] } \\
\text { Ex-ante: Mbaiwa [54] }\end{array}$ & 5 \\
\hline Management & $\begin{array}{l}\text { Fennel and Weaver [18]; Hawkins [25]; Jamal et al. } \\
\text { [32]; Nepal [61]; Northcote and Macbeth [62]; } \\
\text { Osland and Mackoy [66]; Tsaur [85] }\end{array}$ & 7 \\
\hline $\begin{array}{l}\text { Stakeholders } \\
\text { roles and } \\
\text { involvement }\end{array}$ & $\begin{array}{l}\text { Adams and Infield [2]; Garrod [20]; Li [45]; Li [47]; } \\
\text { Palmer [67]; Sithole [76]; Southgate [78] }\end{array}$ & 7 \\
\hline $\begin{array}{l}\text { Communities } \\
\text { attitudes and } \\
\text { intentions }\end{array}$ & $\begin{array}{l}\text { Kuvan and Akan [41]; Lai and Nepal [42]; Sekhar } \\
\text { [73] }\end{array}$ & 3 \\
\hline
\end{tabular}


Table 1: $\quad$ Continued.

\begin{tabular}{|l|l|c|}
\hline \multicolumn{3}{|c|}{ Tourism-Sustainability } \\
\hline $\begin{array}{l}\text { Concepts and } \\
\text { approaches }\end{array}$ & $\begin{array}{l}\text { Choi and Sirakaya [8]; Farrell and Twining-Ward } \\
\text { [17]; Ko [37]; Macbeth et al. [50] }\end{array}$ & 4 \\
\hline $\begin{array}{l}\text { Applications } \\
\text { and methods } \\
\text { to evaluate } \\
\text { sustainability }\end{array}$ & $\begin{array}{l}\text { Cottrell et al. [11]; De la Barre [12]; Gezici [21]; } \\
\text { Helmy [26]; Jamal and Tanase [31]; Johnston and } \\
\text { Tyrrell [35]; Mbaiwa [53]; Mycoo [57]; Parker and }\end{array}$ & 10 \\
\hline
\end{tabular}

In this study the selected papers are classified according to the problem- or concept-oriented modes. As depicted in figure 1, results of this research indicate that about $74 \%$ of the total papers analyzed are problem-oriented whereas only about $8 \%$ of the papers are concept-oriented. Furthermore this analysis suggests that about $18 \%$ of the selected studies are the results of a particular blending of problem- and concept-oriented research. These studies discuss concepts, theories and methods while presenting them in specific contexts or by means of particular case studies. This mix shows the existing link and inter-relation among the two modes of knowledge production.

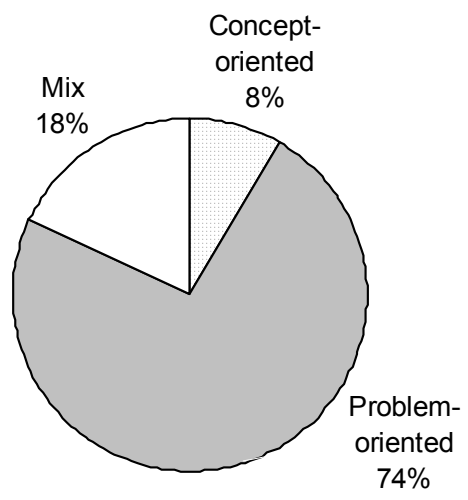

Figure 1: Modes of knowledge production.

\subsection{Analysis of distribution of case studies per region}

The majority of problem-oriented studies and of studies developed through a mix of problem- and concept-oriented research are focusing on the application of specific case studies in a number of regions. Results depicted in figure 2 indicate that case studies examining tourism-poverty issues are highly overlooked. They are completely absent in some critical regions such as South America and Central America seriously suffering from poverty issues. Tourism and nature conservation research is spread in the various regions of the world, especially in Oceania, Europe and Asia. The few sustainable tourism studies are focusing on Europe and Africa. Finally integrated studies on tourism, poverty and nature 


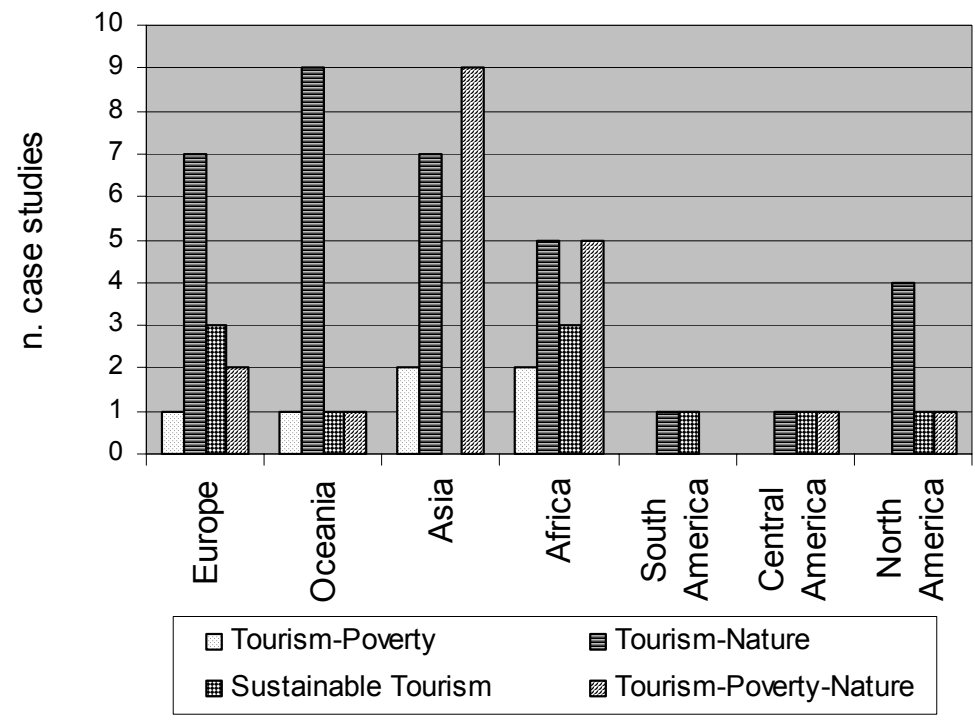

Figure 2: Geographical distribution of case studies.

conservation were mainly carried out in Asia and Africa. In future research, case studies could focus on key areas suffering from poverty and nature degradation issues and overlooked in past studies.

\section{Research opportunities and conclusion}

The vast array of studies especially focusing on problem-oriented and case study driven research could at first give the impression that research carried out in the past years in sustainable tourism, poverty alleviation and nature conservation is very much focused on contributing to enriching knowledge concerning concrete societal issues and needs. A more comprehensive examination of the topics, the research questions and findings of the papers under analysis show that several major societal and global concerns are actually very much overlooked in past studies.

There is a lack of studies focusing and discussing about the contribution of tourism to Millennium Development Goals (MDGs). The UN clearly stated that in 2007, at the midway point between Millennium Development Goals adoption in 2000 and the 2015 target date for achieving these Goals, some countries, for example sub-Saharan Africa, are not on track to achieve any of the Goals (UN [86]). Although the UN, policy makers and researchers stress that the capacity to systematic measure, monitor and report on progress of the various implemented initiatives is at the heart of a sustainable development policy and the achievement of Millennium Goals (Nature [59]; NEPAD [60]; UN [86]) there is a lack of monitoring and evaluation studies investigating the actual contribution of tourism to achieve any of these specific objectives. 
Research efforts in impact and management studies appears to be scattered, empirical studies are lacking, existing approaches lack a coherent and integrated framework around which natural assets and poverty issues can be clustered and managed consistently. Monitoring, evaluation and management frameworks should be developed further in order to take into account the complexity and uncertainty related to the tourism system (Farrell and Twining-Ward [17]). It should be examined what potential value holds the science of complexity for tourism management and governmental and non-governmental policies. Research could focus also on adaptive management as a way of dealing with uncertainty and unpredictability. Furthermore, research should look not only at the overall benefits derived from tourism, but also on equity issues and the distribution of environmental, economic and social benefits among stakeholders and especially among the poor. Additionally, past evaluation studies are almost entirely focusing on ex-post evaluation of arrangements, policies and plans. There is therefore the need to include ex-ante evaluation studies in the research agenda, which can provide useful information when setting up new tourism plans and strategies.

Another important aspect is the need for comparative analysis across destinations. The literature analyzed consists predominantly of case studies about unique destinations in various regions. They provide results and reflections about management, impacts or other specific issues in a specific area. Although it is clear that constraints, challenges and opportunities posed by tourism differ across locations, it appears also evident that there is the need to increase knowledge about critical factors that influence the outcome of tourism for poverty alleviation and nature conservation. Research should therefore attempt to identify and isolate underlying factors across destinations that contributed, or not, to the effectiveness of tourism for poverty and for nature. Rather then providing a fixed set of rules, comparative analysis can provide a set of options and elements upon which to reflect before and during the implementation of certain tourism arrangements and plans. Methodologically there is the need to elaborate new comparative approaches also building on the experience gained in the development and application of comparative methodologies in other fields within social science (Pearce [69]).

Since a number of years societal organizations point out that tourism can play a very important role in providing sustainable financing for protected areas and creating incentive measures for managing natural resources and for supporting the poor. However, currently besides (entrance and user) fees, taxes and sitespecific negotiation, or donation not much was done in order to develop innovative types of payment schemes and investigated their profitability and the impact of such schemes on the locals and on the poor. Research can contribute by providing knowledge about the application and the effectiveness of current mechanisms and by increasing their level of sophistication. New arrangements should therefore be investigated. Furthermore, attention should be given to the role of the poor in potential partnerships and arrangements. The modes of participation of poor communities should be further investigated by taking into account local socio-political-institutional constraints. Research could also 
explore various manners for social and political empowerment of local communities.

Additionally the development of concept-oriented research is needed in order to provide the philosophical, conceptual and methodological ground upon which practical research can be implemented. Future research could focus on critically examining tourism and its role for nature conservation and poverty. Especially it should focus on the role of tourism for poverty and the multi-dimensions of poverty, considering that there is a lack of studies addressing these issues. Research studies could also focus on investigating the evolution of the concept and meaning of sustainability for tourism and vice versa.

A research agenda is therefore required to promptly address and investigate these and other urgent critical issues in order to contribute to the production of scientifically robust and socially meaningful knowledge at a global and local level.

\section{References}

[1] Alpizar, F., The pricing of protected areas in nature-based tourism: A local perspective. Ecological Economics 56, pp. 294-307, 2006.

[2] Adams, W.M. \& Infield, M., Who is on the Gorilla's Payroll? Claims on Tourist Revenue From a Ugandan National Park. World Development, 31(1), pp. 177-190, 2003.

[3] Buckley, R., Partnerships in ecotourism: Australian political frameworks. International Journal of Tourism Research, 6, pp. 75-83, 2004.

[4] Buultjens, J., Ratnayake, I., Gnanapala, A. \& Aslam A., Tourism and its implications for management in Ruhuna National Park (Yala), Sri Lanka. Tourism Management, 26, pp. 733-742, 2005.

[5] Brown, G., Mapping landscape values and development preferences: a method for tourism and residential development planning. International Journal of Tourism Research, 8, pp. 101-113, 2006.

[6] Briedenhann, J. \& Wickens E., Tourism routes as a tool for the economic development of rural areas - vibrant hope or impossible dream? Tourism Management, 25(1), pp. 71-79, 2004.

[7] Cheng, Z., Zhang, J., Wu, B. \& Niu, L., Relationship Between Tourism Development and Vegetated Landscapes in Luya Mountain Nature Reserve, Shanxi, China. Environmental Management, 36(3), pp. 374-381, 2005.

[8] Choi, H.C. \& Sirakaya E., Sustainability indicators for managing community tourism. Tourism Management, 27, pp. 1274-1289, 2006.

[9] Clarke, J., Trade Associations: An Appropriate Channel for Developing Sustainable Practice in SMEs? Journal of Sustainable Tourism 12(3), pp. 194-208, 2004.

[10] Clifton, J. \& Benson A., Planning for Sustainable Ecotourism: The Case for Research Ecotourism in Developing Country Destinations. Journal of Sustainable Tourism, 14(3), pp. 238-254, 2006. 
[11] Cottrell, S., Van der Duim, R., Ankersmid, P. \& Kelder, L., Measuring the Sustainability of Tourism in Manuel Antonio and Texel: A Tourist Perspective. Journal of Sustainable Tourism, 12(5), pp. 409-431, 2004.

[12] De la Barre, S., Not 'Ecotourism'?: Wilderness Tourism in Canada's Yukon Territory. Journal of Ecotourism, 4(2) pp. 92-107, 2005.

[13] De Oliveira, J.A.P., Tourism as a Force for Establishing Protected Areas: The Case of Bahia, Brazil. Journal of Sustainable Tourism 13(1), pp. 24-49, 2005.

[14] Dyer, P., Aberdeen, L. \& Schuler, S., Tourism impacts on an Australian indigenous community: a Djabugay case study. Tourism Management, 24(1), pp. 85-95, 2003.

[15] Duffy, R., Global Environmental Governance and the Politics of Ecotourism in Madagascar. Journal of Ecotourism, 5 (1\&2), pp.128-144, 2006.

[16] Fairweather, J.R., Maslin, C. \& Simmons D.G., Environmental Values and Response to Ecolabels Among International Visitors to New Zealand. Journal of Sustainable Tourism, 13(1), pp.82-98, 2005.

[17] Farrell, B. \& Twining-Ward, L., Seven Steps Towards Sustainability: Tourism in the Context of New Knowledge. Journal of Sustainable Tourism, 13(2), pp. 109-122, 2005.

[18]Fennel, D. \& Weaver, D., The Ecotourism Concept and TourismConservation Symbiosis. J. of Sustainable Tourism 13(4), pp.373-390, 2005.

[19] Fennell, D.A. \& Butler, R.W., A human ecological approach to tourism interactions. International Journal of Tourism Research 5, pp.197-210, 2003

[20] Garrod, D., Local Participation in the Planning and Management of Ecotourism: A Revised Model Approach. Journal of Ecotourism, 2, pp.3353, 2003.

[21] Gezici, F., Components of sustainability: two cases from Turkey. Annals of Tourism Research, 33(2), pp. 442-455, 2006.

[22] Gios, G., Goio, I., Notaro, S. \& Raffaelli, R., The value of natural resources for tourism: a case study of the Italian Alps. International Journal of Tourism Research, 8, pp. 77-85, 2006.

[23] Gossling, S., Market integration and ecosystem degradation: is sustainable tourism development in rural communities a contradiction in terms? Environment, Development and Sustainability, 5(3\&4), pp. 383-400, 2003.

[24] Hannam, K., Tourism Management Issues in India's National Parks: An Analysis of the Rajiv Gandhi (Nagarahole) National Park. Current Issues in Tourism, 8, 2\&3, pp.165-180, 2005.

[25] Hawkins, E., A Protected Areas Ecotourism Competitive Cluster Approach to Catalyse Biodiversity Conservation and Economic Growth in Bulgaria. Journal of Sustainable Tourism, 12(3), pp. 219-244, 2004.

[26] Helmy, E., Towards Integration of Sustainability into Tourism Planning in Developing Countries: Egypt as a Case Study. Current issues in Tourism, 2, 6, pp. 478-501, 2004. 
[27] Henderson, J.C., Planning, Changing Landscapes and Tourism in Singapore. Journal of Sustainable Tourism, 13(2), pp. 123-135, 2005.

[28] Herremans, I.M., Reid, R.E. \& Wilson, L.K., Environmental Management Systems (EMS) of Tour Operators: Learning from Each Other. Journal of Sustainable Tourism, 13(4), pp. 311-338, 2005.

[29] Hill, W. \& Pickering C.M., Vegetation associated with different walking track types in the Kosciuszko alpine area, Australia. Journal of Environmental Management, 78, pp. 24-34, 2006.

[30] Holden, A., Achieving a Sustainable Relationship Between Common Pool Resources and Tourism: The Role of Environmental Ethics. Journal of Sustainable Tourism, 13(4), pp. 339-352, 2005.

[31] Jamal, T. \& Tanase, A. Impacts and Conflicts Surrounding Dracula Park, Romania: The Role of Sustainable Tourism. Journal of Sustainable Tourism, 13(5), pp. 440-445, 2005.

[32] Jamal, T., Borges, M., Stronza, A., The Institutionalisation of Ecotourism: Certification, Cultural Equity and Praxis. Journal of Ecotourism, 5, 3, pp. $175,2006$.

[33] Jamal, T., Everett, J. \& Dann G.M.S., Ecological Rationalization and Performative Resistance in Natural Area Destinations. Tourist Studies, 3, pp. 143-169, 2003.

[34] Jogaratnam, G., Chon, K., McCleary, K., Mena M. \& Yoo, J., An analysis of institutional contributors to three major academic tourism journals: 19922001. Tourism Management 26, pp. 641-648, 2005.

[35] Johnston, R.J. \& Tyrrell, T.J., A Dynamic Model of Sustainable Tourism. Journal of Travel Research, 44, pp. 124-134, 2005.

[36] Kenneth, F.D., Hughey, K.F.D., Ward, J. C., Crawford, K. A., McConnell, L., Phillips, J.G. \& Washbourne, R., A classification framework and management approach for the sustainable use of natural assets used for tourism. International Journal of Tourism Research, 6, 349-363, 2004.

[37] Ko, T.G., Development of a tourism sustainability assessment procedure: a conceptual approach. Tourism Management, 26, 431-445, 2005.

[38] Kontogeorgopoulos, N., Community-Based Ecotourism in Phuket and Ao Phangnga, Thailand: Partial Victories and Bittersweet Remedies. Journal of Sustainable Development. 13(1), pp. 4-23, 2005.

[39] Kruger, O., The role of ecotourism in conservation: panacea or Pandora's box? Biodiversity and Conservation, 14, pp.579-600, 2005.

[40] Kuvan, Y., The use of forests for the purpose of tourism: the case of Belek Tourism Center in Turkey. Journal of Environmental Management, 75, pp. 263-274, 2005

[41] Kuvan, Y. \& Akan P., Residents' attitudes toward general and forest-related impacts of tourism: the case of Belek, Antalya. Tourism Management 26, pp. 691-706, 2005.

[42] Lai, P. \& Nepal, S.K., Local perspectives of ecotourism development in Tawushan Nature Reserve, Taiwan. Tourism Management, 27, pp.11171129, 2006. 
[43] Lengkeek, J. \& Platenkamp, V., The kaleidoscope of tourism studies. Paper presented at the ISA conference, July 2006, Durban, South Africa, 2006.

[44] Lewis, A. \& Newsome, D., Planning for stingray tourism at Hamelin Bay, Western Australia: the importance of stakeholder perspectives. International Journal of Tourism Research, 5, pp. 331-346, 2003.

[45] Li, W., Community decision making. Participation in Development. Annals of Tourism Research, 33(1), pp. 132-143, 2006.

[46] Li., W., Environmental management indicators for ecotourism in China's nature reserves: A case study in Tianmushan Nature Reserve. Tourism Management 25(5), pp.559-564, 2004.

[47] Li, Y., Exploring Community Tourism in China: The Case of Nanshan Cultural Tourism Zone. Journal of Sustainable Tourism 12(3), pp. 175-193. 2004.

[48] Li, W., Zhang, Q., Liu, E.C. \& Xue, Q., Tourism's Impacts on Natural Resources: A Positive Case from China. Environmental Management, 38, pp. 572-579, 2006.

[49] Li, W., Ge, X. \& Liu, C., Hiking trails and tourism impact assessment in protected area: Juzhaigou biosphere reserve, China. Environmental Monitoring and Assessment, 108, pp. 279-293, 2005.

[50] Macbeth, J., Carson, D., Northcote, J., Social Capital, Tourism and Regional Development: SPCC as a Basis for Innovation and Sustainability. Issues in Current Tourism, 7(6), pp. 502-522, 2004.

[51] Masau, P., \& Brideaux, B., Sustainable Tourism: A Role for Kenya's Hotel Industry. Issues in Tourism, 6(3), pp. 197-208, 2003.

[52] Mason, P., Visitor Management in Protected Areas: From 'Hard' to 'Soft' Approaches? Issues in Current Tourism, 8(2\&3), pp. 181-194, 2005.

[53] Mbaiwa, J.E., The Problems and Prospects of Sustainable Tourism Development in the Okavango Delta, Botswana. Journal of Sustainable Tourism, 13(3), pp. 203-227, 2005.

[54] Mbaiwa, E.J., Prospects of basket production in promoting sustainable rural livelihoods in the Okavango Delta, Botswana. Journal of Tourism Research, 6, pp. 221-235, 2004.

[55] MEA (Millennium Ecosystem Assessment), Ecosystems and human wellbeing. Synthesis. Island Press, Washington, D.C., 2005.

[56] Medina, L.K., Ecotourism and Certification: Confronting the Principles and Pragmatics of Socially Responsible Tourism. Journal of Sustainable Tourism 13(3), pp. 281-295, 2005.

[57] Mycoo, M., Sustainable Tourism Using Regulations, Market Mechanisms and Green Certification: A Case Study of Barbados. Journal of Sustainable Tourism, 14(5), pp. 489-511, 2006.

[58] Naidoo, R. \& Adamowicz, W.L., Biodiversity and nature-based tourism at forest reserves in Uganda. Environment and Development Economics, 10, pp. 159-178, 2005.

[59] Nature, Millennium Development Holes. Nature, editorial, 446, 347, 2007.

[60] NEPAD, The New Partnership for Africa's Development. 2001, Abuja, Nigeria, see www.nepad.org, consulted January 2008. 
[61] Nepal, K., Indigenous Ecotourism in Central British Columbia: The Potential for Building Capacity in the Tl'azt'en Nations Territories. Journal of Ecotourism, 3, 3, pp. 173-194, 2004.

[62] Northcote, J. \& Macbeth, J., Conceptualizing yield: Sustainable Tourism Management. Annals of Tourism Research, 33(1), pp. 199-220, 2006.

[63] Nyaupane, G., Morais, D. \& Dowler, L., The role of community involvement and number/type of visitors on tourism impacts: A controlled comparison of Annapurna, Nepal and Northwest Yunnan, China. Tourism Management 27(6), pp. 1337-1385, 2006.

[64] Nyaupane, G. P., Morais, D. B. \& Graefe, A.R., Nature tourism constraints, a cross-activity comparison. Annals of tourism research, 31(3), pp. 540-555, 2004.

[65] Okello, M.M. \& Kiringe, J.W. Threats to Biodiversity and their Implications in Protected and Adjacent Dispersal Areas of Kenya. Journal of Sustainable Tourism 12(1), pp. 55-69, 2004.

[66] Osland, G. \& Makoy, R., Ecolodge Performance Goals and Evaluations. Journal of Ecotourism, 3, 2, pp. 109-128, 2004.

[67] Palmer, N., Economic Transition and the Struggle for Local Control in Ecotourism Development: The Case of Kyrgyzstan. Journal of Ecotourism, 5(1\&2) pp. 40-61, 2006.

[68] Parker, S., Khare, A., Understanding Success Factors for Ensuring Sustainability in Ecotourism Development in Southern Africa. Journal of Ecotourism, 4(1), pp. 32-46, 2005.

[69] Pearce, D., Comparative studies in tourism research. In D. G. Pearce, \& R. W. Butler (Eds.), Tourism research, critiques and challenges, London, Routledge, pp. 20-35, 1993.

[70] Phillips, M.R. \& Jones, A.L., Erosion and tourism infrastructure in the coastal zone: Problems, consequences and management. Tourism Management, 27, pp. 517-524, 2006.

[71] Priskin, J., Tourist Perceptions of Degradation Caused by Coastal NatureBased Recreation. Environmental Management, 32(2), pp. 189-204, 2003.

[72] Saayman, M. \& Saayman, A. Creating a framework to determine the socioeconomic impact of national parks in South Africa: a case study of the Addo Elephant National Park. Tourism Economics, 12(4), pp. 619-633, 2006.

[73] Sekhar, N.U., Local people's attitudes towards conservation and wildlife tourism around Sariska Tiger Reserve, India. Journal of Environmental Management 69, pp. 339-347, 2003.

[74] Shultis, J.D. \& Way, P.A., Changing Conceptions of Protected Areas and Conservation: Linking Conservation, Ecological Integrity and Tourism Management. Journal of Sustainable Tourism, 14(3), pp. 223-237, 2005.

[75] Silori, C.S., Socio-economic and ecological consequences of the ban on adventure tourism in Nanda Devi Biosphere Reserve, western Himalaya. Biodiversity and Conservation 13, pp. 2237-2252, 2004.

[76] Sithole, E., Trans-boundary Environmental Actors: The Zambezi Society's Campaign for Sustainable Tourism Development in the Zambezi Bioregion. Journal of Sustainable Tourism, 13(5), pp. 486-503, 2005. 
[77] Sorice, M.G, Shafer, C.S. \& Ditton, R.B., Managing Endangered Species Within the Use-Preservation Paradox: The Florida Manatee (Trichechus manatus latirostris) as a Tourism Attraction. Environmental Management, 37(1), pp. 69-83, 2006.

[78] Southgate, C., Ecotourism in Kenya: The Vulnerability of communities. Journal of Ecotourism, 5(1\&2) pp. 80-96, 2006.

[79] Spenceley, A., Nature-based Tourism and Environmental Sustainability in South Africa. Journal of Sustainable Tourism, 13(2), pp. 136-170, 2006.

[80] Stein, T., Clark, J., Rickards, J., Assessing Nature's Role in Ecotourism Development in Florida: Perspectives of Tourism Professionals and Government Decision-makers. Journal of Ecotourism, 2, pp.155-172, 2003.

[81] Stone, M. \& Wall, G., Ecotourism and Community Development: Case Studies from Hainan, China. Environ. Management, 33(1), pp. 12-24, 2004.

[82] Svoronou, E. \& Holden, A., Ecotourism as a tool for nature conservation. The role of WWF Greece in the Dadia-Lefkimi-Soufli Forest Reserve in Greece. Journal of Sustainable Tourism, 13(5), pp. 456-467, 2006.

[83] Tisdell, C. \& Wilson, C., Perceived impacts of ecotourism on environmental learning and conservation: turtle watching as a case study. Environment, Development and Sustainability, 7, pp. 291-302, 2005.

[84] Tosun, C., Expected nature of community participation in tourism development. Tourism Management, 27, pp. 493-504, 2006.

[85] Tsaur, S., Lin, Y. \& Lin J., Evaluating ecotourism sustainability from the integrated perspective of resource, community and tourism. Tourism Management 27(4), pp. 640-653, 2005.

[86] U.N., Millennium Development Goals Report. New York, 2007.

[87] Van der Duim, R. \& van Marwijk, R., The Implementation of an Environmental Management System for Dutch Tour Operators: An Actornetwork Perspective. Journal of Sustainable Tourism, 14, pp.449-472, 2006.

[88] Van der Duim R. \& Caalders, J., The Margins of Texel. Journal of Sustainable Tourism, 12(5), pp. 367-387, 2004.

[89] Wachowiak, H., Large Protected Areas and Visitor Information Management in Germany. Current Issues in Tourism, 8, pp. 245-257, 2005.

[90] World Bank, Attacking poverty: World Development Report 2000-01. New York. Oxford University Press, 2000.

[91] Wurzinger, S. \& Johansson, M., Environmental Concern and Knowledge of Ecotourism among Three Groups of Swedish Tourists. Journal of Travel Research, 45, pp. 217-226, 2006.

[92] Xiao, H. \& Smith, S.L.G., The making of tourism research. Insights from a social science journal. Annals of Tourism Research, 33(2), pp. 490-507, $2006 a$.

[93] Xiao, H., \& Smith, S.L.G., Case Studies in tourism research: A state of the art analysis. Tourism Management, 27, pp. 738-749, $2006 \mathrm{~b}$. 